\title{
Dissecting inhibitory brain circuits with genetically-targeted technologies
}

\author{
Dona K. Murphey ${ }^{1}$, Alexander M. Herman ${ }^{2}$ and Benjamin R. Arenkiel ${ }^{2,3,4,5}$ \\ ${ }^{1}$ Department of Neurology, Baylor College of Medicine, Houston, TX, USA \\ 2 Program in Developmental Biology, Baylor College of Medicine, Houston, TX, USA \\ ${ }^{3}$ Department of Molecular and Human Genetics, Baylor College of Medicine, Houston, TX, USA \\ ${ }^{4}$ Department of Neuroscience, Baylor College of Medicine, Houston, TX, USA \\ ${ }^{5}$ Jan and Dan Duncan Neurological Research Institute at Texas Children's Hospital, Houston, TX, USA
}

\section{Edited by:}

Mariano Soiza-Reilly, Institut

National de la Santé et de la

Recherche Médicale, France

Reviewed by:

Michael M. Halassa, Massachusetts Institute of Technology, USA

Stephen Shea, Cold Spring Harbor

Laboratory, USA

*Correspondence:

Dona K. Murphey, Department of

Neurology, Baylor College of

Medicine, One Baylor Plaza,

Houston, TX 77030, USA

e-mail:dk140085@bcm.edu
The evolution of genetically targeted tools has begun to allow us to dissect anatomically and functionally heterogeneous interneurons, and to probe circuit function from synapses to behavior. Over the last decade, these tools have been used widely to visualize neurons in a cell type-specific manner, and engage them to activate and inactivate with exquisite precision. In this process, we have expanded our understanding of interneuron diversity, their functional connectivity, and how selective inhibitory circuits contribute to behavior. Here we discuss the relative assets of genetically encoded fluorescent proteins (FPs), viral tracing methods, optogenetics, chemical genetics, and biosensors in the study of inhibitory interneurons and their respective circuits.

Keywords: interneurons, optogenetics, chemical genetics, viral tracing, channelrhodopsin, interneuron diversity

\section{INTRODUCTION}

Interneurons subserve sensory processing (Lee et al., 2012, 2013; Hamilton et al., 2013; Pfeffer et al., 2013; Fu et al., 2014), movement (Brown et al., 2014), learning (Kravitz et al., 2012), reward (Witten et al., 2010; van Zessen et al., 2012), and disease (Gradinaru et al., 2009; Kravitz et al., 2010; Krook-Magnuson et al., 2013; Peng et al., 2013; Brown et al., 2014; Cho and Sohal, 2014; Ledri et al., 2014), and genetic technologies allow for their targeted study (Taniguchi et al., 2011; Kepecs and Fishell, 2014). Various molecular, morphological, and electrophysiological properties (Ascoli et al., 2008) delimit interneuron diversity. Molecular features can be used to investigate whether cell shape or passive and active membrane properties of neurons in circuits of interest represent(s) a homogeneous class (Taniguchi et al., 2013), and morphological and electrophysiological properties of the neurons that express a characteristic marker can further elaborate within class diversity of molecularly defined populations. Additional strategies can then be used to iteratively refine molecular heterogeneity (Ma et al., 2006; Runyan et al., 2010; Chittajallu et al., 2013; Povysheva et al., 2013; Sohn et al., 2014).

Many molecular features arise from post-mitotic celltype specification by changes in receptor expression, cellintrinsic activity, and the activity of connected partners to modify a handful of mutually exclusive cardinal classes. Genetically targeted tools for marking and manipulating neuronal activity differentially exploit molecular expression to delimit interneuronal subtypes. In particular, the widespread application of conditionally-expressed fluorescent proteins (FPs) (Hadjantonakis et al., 2003; Livet et al., 2007), virally mediated anatomical tracers (Wickersham et al., 2007; Beier et al., 2011), optogenetic reporters (Zhang et al., 2006; Berndt et al., 2014), designer receptors exclusively activated by designer drugs (DREADD receptors) (Wess et al., 2013), and genetically-encoded subcellular biosensors (Hodgson et al., 2008; Tantama et al., 2012; Glykys et al., 2014), has allowed us dissect the contributions of specific interneurons and even their subcellular compartments to circuit function, behavior, and disease in genetically tractable mice. We discuss the benefits and challenges of these methods first with an eye to how we target the interneurons of interest for investigation.

\section{STRATEGIES FOR GENOMIC TARGETING OF INTERNEURONS}

Recapitulating endogenous gene expression is key to cell typespecific study (Luo et al., 2008) and can be achieved by standard, bacterial artificial chromosome (BAC) (Heintz, 2001; Ting and Feng, 2014), and site-directed transgenic methods. Standard and BAC transgenic methods both rely on random integration, which may help to study interneuron subpopulations that express the same cis-regulatory elements. However, sitedirected integration, made possible through integrases or gene targeted knockins, more faithfully recapitulates endogenous gene expression and is therefore often preferred. Binary expression systems and/or conditional mutagenesis based on site-directed DNA recombination confer even greater experimental reliability and flexibility (Garcia-Otin and Guillou, 2006; Miyoshi et al., 2010).

It is important to note that the cell type-specificity of genetic targeting relies on accurate endogenous promoter expression. 
To aid in this effort there is a rapidly evolving set of comprehensive gene expression data for the mouse brain during development, and across different areas in adult brain tissue (Allen Brain Atlas, www.brain-map.org, and GENSAT, www. gensat.org). Established Cre driver lines (Kimura et al., 1996; Qiu et al., 1997; Schurmans et al., 1997; Schwaller et al., 1999; Kerr et al., 2000; Gyurko et al., 2002; Misgeld et al., 2002; Qian et al., 2002; Robledo et al., 2002; Kusakabe et al., 2006; Chattopadhyaya et al., 2007; Liodis et al., 2007; Taniguchi et al., 2011; Wang et al., 2014) (Table 1) have to date provided the greatest genetic traction on neocortical interneurons (Taniguchi, 2014) and local and long-range inhibitory neurons of the striatum (Brown et al., 2014; Nelson et al., 2014) and hippocampus (Melzer et al., 2012; Kepecs and Fishell, 2014). It is of note, however, that lineage-specific patterns of gene expression can carry into unanticipated cell types in other parts of the brain or body through early recombination events. Because only static patterns of cortical and hippocampal expression have been extensively characterized (Taniguchi et al., 2011), expression validation is critical. But, importantly, lineage effects can be co-opted by temporally restricted inducible transgenes (Rothermel et al., 2013) in order to study the developmental expression (Dymecki and Kim, 2007; Kumar et al., 2013) of cell-type-specific promoters. Complementary virus-mediated transgene expression in adult brain tissue might avoid lineage-associated issues by only targeting cell types that express a given marker at the time of viral delivery.

\section{VIRAL DELIVERY OF GENETICALLY ENCODED TOOLS IN INTERNEURONS}

Restriction of a reporter to a subset of neurons in a given brain area or developmental time point can be achieved by viral delivery of genetic constructs driven by cell type-specific promoters. Viral delivery of transgenes driven by short promoters (Nathanson et al., 2009) has not effectively captured a genetically homogeneous subpopulation of neurons, but conditional Cre-dependent [e.g., Flip Excision (Flex) (Schnutgen et al., 2003) or Lox-StopLox] transgenes driven by strong ubiquitous promoters segregate neurons spatially and temporally in a way not possible through genomic strategies. Viral injections are constrained by their physical properties, however. Viral genome size limits the size of the genetic constructs viruses can carry, and efficiency of uptake and direction of infectivity (Rothermel et al., 2013) depend on viral capsid serotype, genetic construct (Betley and Sternson, 2011), and the targeted brain region (Taymans et al., 2007). Controls should ensure that successful viral infection does not alter cell function. Acknowledging these caveats, gene targeting through both conventional strategies, and virus-mediated transgene delivery, offer an increasingly powerful reserve of anatomical and functional tools we highlight below.

\section{GENETICALLY ENCODED ANATOMICAL DISSECTION OF INTERNEURONS}

Interneurons assume diverse somatic shapes and patterns of dendritic/axonal arborization in cortical (Markram et al., 2004; Ascoli

Table 1 | Useful mouse lines for commonly studied interneurons.

\begin{tabular}{|c|c|c|c|c|}
\hline Gene name & Cre/Cre-ER/Tet & Knockout & $\begin{array}{l}\text { Fluorescent/Functional } \\
\text { reporter }\end{array}$ & References \\
\hline Agrp & Cre $^{\text {Jax }}$, Cre-ER & Germline & N/A & Qian et al., 2002; Wang et al., 2013 \\
\hline Avp & Cre ${ }^{\mathrm{Jax}}$ & Conditional ${ }^{\mid \mathrm{MSR}}$ & GFPMMRRC & \\
\hline Calb2 & Cre ${ }^{\text {Jax }}$, Cre-ER & Germline & GFPMMRRC & Schurmans et al., 1997 \\
\hline Cck & Cre ${ }^{\text {Jax }}$, Cre-ER & Germline $^{\text {Jax }}$ & GFPMMRRC & \\
\hline Chat & Cre ${ }^{\text {Jax }}$, Cre-ER & Germline, Conditional Jax & GFPJax, Chat-Chr2::eYFPJax & Misgeld et al., 2002 \\
\hline Crh & $\mathrm{Cre}^{\mathrm{Jax}}$ & Germline $^{\text {Jax }}$ & GFPMMRRC & \\
\hline Dlx1 & Cre ${ }^{M M R R C}$, Cre-ER ${ }^{\text {Jax }}$ & Germline & tdTomatoMMRRC & Qiu et al., 1997 \\
\hline Dlx5/6 & $\mathrm{Cre}^{\mathrm{Jax}}, \mathrm{Cre}-\mathrm{ER}^{\mathrm{Jax}}$ & Germline & GFPJax $^{\prime}$ & Robledo et al., 2002 \\
\hline Gad1 (Gad67) & Cre & Germline $^{\text {Jax }}$, Conditional & GFPJax & $\begin{array}{l}\text { Chattopadhyaya et al., 2007; } \\
\text { Taniguchi et al., } 2011\end{array}$ \\
\hline Gad2 (Gad65) & $\mathrm{Cre}^{\mathrm{Jax}}$, Cre-ER ${ }^{\mathrm{Jax}}$ & Germline $^{\text {Jax }}$ & GFPMMRRC, mCherry ${ }^{\mathrm{Jax}}$ & \\
\hline Gal (Galanin) & Cre $\mathrm{MMRRC}^{\mathrm{MM}}$ & Germline & GFPMMRRC & Kerr et al., 2000 \\
\hline Lhx6 & Cre-ER ${ }^{\mathrm{Jax}}$ & Germline & GFPMMRRC & Liodis et al., 2007 \\
\hline Nos1 & Cre ${ }^{\text {Jax }}$, Cre-ER ${ }^{\text {Jax }}$ & Germline $^{J a x}$, Conditional & GFPMMRRC & Gyurko et al., 2002 \\
\hline $\mathrm{Nk} \times 2.1$ & Cre $^{\text {Jax }}$, Cre-ER $^{\text {Jax }}$ & Germline, Conditional & GFPMMRRC & $\begin{array}{l}\text { Kimura et al., 1996; Kusakabe } \\
\text { et al., } 2006\end{array}$ \\
\hline Pvalb & Cre $^{\text {Jax }}$, Cre-ER ${ }^{\text {Jax }}$, Tet-OffJax & Germline & $\begin{array}{l}\text { GFPMMRRC, } \\
\text { Pvalb-Chr2::eYFPJax }\end{array}$ & Schwaller et al., 1999 \\
\hline Slc32a1 (Vgat) & Cre $^{\mathrm{Jax}}$, Cre-ER $^{\mathrm{Jax}}$ & Germline $^{\text {Jax }}$, Conditional $^{\text {Jax }}$ & $\begin{array}{l}\text { GFPMMRRC, } \\
\text { Vgat-Chr2::eYFPJax }\end{array}$ & \\
\hline Sst & Cre $^{\text {Jax }}$, Cre-ER ${ }^{\text {Jax }}$, Tet-Off ${ }^{J a x}$ & Germline Jax $^{\text {Jax }}$ & $\mathrm{N} / \mathrm{A}$ & \\
\hline Npy & Cre ${ }^{M M R R C}$, Tet-OffJax & Germline $^{\mathrm{Jax}}$ & GFPJax & \\
\hline Vip & Cre ${ }^{\mathrm{Jax}}$ & Germline Jax $^{\text {Jax }}$ & GFPMMRRC & \\
\hline
\end{tabular}

Availability index: Jax, Jackson Laboratory; MMRRC, Mutant Mouse Regional Resource Center; IMSR, International Mouse Strain Resource. 
et al., 2008) and subcortical structures (Petryszyn et al., 2014). Certain morphologies tend to elaborate certain electrophysiological properties, but there is both variability and overlap of form and function. While some fundamental features are conserved within classes (Rudy et al., 2011; Pfeffer et al., 2013), we still find notable heterogeneity among even well-described groups (Ma et al., 2006; Runyan et al., 2010; Chittajallu et al., 2013; Povysheva et al., 2013; Sohn et al., 2014). Dissecting this heterogeneity has become tractable with genetically-encoded FPs (Hadjantonakis et al., 2003; Livet et al., 2007; Kremers et al., 2011) whose cell-fill and membrane-directed expression has allowed for real-time visualization of interneurons in intact functional preparations such as juxtacellular recording or calcium imaging (Tukker et al., 2007; Kato et al., 2013; Chiovini et al., 2014; Lee et al., 2014) as well as more precise surveys of circuit connectivity. FPs have also been useful for certain neuropeptidergic subclasses of interneurons such as SST and VIP, in which the extensive processing of propeptides and the extra-somatic localization of their products have made these cell types difficult to visualize using conventional immunohistochemistry (Nassel, 1993). It is important to recognize that FPs exhibit variable stability (turnover, photo/pH/temperature stability) subject to differential regulation in each cell type. To better characterize cell shape and connectivity, however, genetically targeted FP expression offers a good promontory. The use of neurotropic viruses further reveals circuit connectivity of specific cell types.

Neurotropic viruses selectively infect neurons. Polysynaptic, monosynaptic, anterograde, and retrograde transport of viral vectors for cell labeling are now possible (Kuypers and Ugolini, 1990; Zemanick et al., 1991; Enquist and Card, 2003). One of the first viral tracing vectors to be implemented was modified herpes simplex virus (HSV), which shows both anterograde and retrograde transport and has recently been engineered to be cre-dependent for greater cell type-specificity (Lo and Anderson, 2011). HSV can be used to establish the polysynaptic connectivity of a circuit, but this viral tracing approach has been limited by cytotoxicity. Emergent methods for genetically-encoded monosynaptic viral tracing (Wickersham et al., 2007; Beier et al., 2011) now offer more sophisticated alternatives toward dissecting neuronal circuits. Using genetically engineered rabies virus (RV), alongside pseudotyping and cell type specific targeting approaches (Wall et al., 2010; Weible et al., 2010), we can now safely query monosynaptic inputs onto cells. Moreover, RV can encode dual fluorescent and functional reporters, such that monosynaptic pairs can be visualized and manipulated dynamically (Osakada et al., 2011).

As powerful as the new viral vectors are toward revealing brain connectivity, interpreting genetically targeted monosynaptic tracing studies in interneuronal circuits can be vexing. Interneurons, more so than principal excitatory neurons, promiscuously synapse onto other inhibitory cells in order to exert disinhibitory control in development (Kuhlman et al., 2013) and in the adult brain (Lee et al., 2013; Pfeffer et al., 2013; Pi et al., 2013; Xu et al., 2013). Reciprocal intraclass chemical synapses and/or electrical gap junctions coordinate activity across large populations of neurons (Tamas et al., 1998, 2000; Chiu et al., 2013; Hioki et al., 2013) and over considerable distances (Buzsaki et al., 2004; Caputi et al., 2013), confounding the identification of presynaptic-postsynaptic partners. Polysynaptic tracers and functional tools can be further implemented to clarify connectivity.

\section{GENETICALLY ENCODED FUNCTIONAL DISSECTION OF INHIBITORY CIRCUITS}

Recently, the light-activated non-specific cation channel channelrhodopsin-2 (ChR2) and its variants (Mattis et al., 2012) have been extremely valuable toward unraveling fundamentals of functional connectivity both ex vivo and in vivo (Huang et al., 2013; Jennings et al., 2013; Stamatakis et al., 2013; Halassa et al., 2014; Roux et al., 2014; Siegle and Wilson, 2014; Sparta et al., 2014). However, the interpretation of optogenetic manipulations in inhibitory neurons must be approached with some caution given the diversity of cell type-specific responses to photic stimulation. For example, using varying light stimulation parameters to activate different ChR2-expressing cell types, we learned that cortical somatostatin-positive interneurons exhibit heterogeneous firing properties, and that all regular-spiking interneuron subtypes evaluated including somatostatin, corticotropinreleasing hormone $(\mathrm{CRH})$, and cholinergic interneurons could be functionally silenced, rather than activated, when photically stimulated with prolonged light pulses (Herman et al., 2014). An appropriate strategy would be to first identify the effect of stimulation on the cell type of interest using intracellular recordings or imaging techniques in order to avoid confounding interpretations at the level of post-synaptic electrophysiological probes and/or behavioral readouts. Any differential responses to optogenetic activation may then help to further subclassify interneurons.

As an alternative, or in parallel with optogenetic activation by ChR2, inhibition through light-activated chloride pumps (halorhodopsins) (Gradinaru et al., 2008; Tye et al., 2011) or proton pumps (archaerhodopsins) (Madisen et al., 2012; Beppu et al., 2014) allows us to query the direct circuit effect of temporally precise neuronal silencing. Whereas the light-gated activators have been relatively robust to engineering, the inhibitors have required ongoing reengineering to address issues such as intracellular accumulation/aggregation (halorhodopsins) and limited hyperpolarization due to proton pump kinetics (archaerhodopsins). Recently, two different groups developed an appealing alternative to inhibitory pumps by site-directed mutagenesis of channelrhodopsin, transforming it into a chloride-conducting channel. Notably, inhibitory channels have proven to be more efficient than ion pumps due to independence from photon-gated movement of individual ions, and preservation of normal electrochemical gradients (Berndt et al., 2014; Wietek et al., 2014). Reversibly silencing inhibitory interneurons can be quite useful with our growing knowledge of the behavioral contingencies that determine interclass activity differences (Letzkus et al., 2011; Lapray et al., 2012; Pi et al., 2013), as well as their differential role in network oscillations (Roux et al., 2014). This genetically targeted manipulation can also be used in the study of diseases with an evolving dysfunction of specific interneuronal cell types (Gernert et al., 2000, 2002; Kalanithi et al., 2005; Kataoka et al., 2010; Gittis et al., 2011; Kim et al., 2014), particularly to examine trial-bytrial, or time-locked variability in electrophysiology and behavior in the disease state. 
Table 2 | Common genetically-targeted technologies in neuroscience research.

\begin{tabular}{|c|c|c|c|c|c|}
\hline & & & Strengths & Challenges & References \\
\hline \multirow[t]{3}{*}{ Anatomical } & $\begin{array}{l}\text { Genetically- } \\
\text { encoded } \\
\text { fluorescent } \\
\text { proteins }\end{array}$ & $\begin{array}{l}\text { GFP, RFP, BFP, } \\
\text { etc. }\end{array}$ & $\begin{array}{l}\text { Can visualize soma or projections, } \\
\text { can be tagged with functional } \\
\text { reporters or overexpression } \\
\text { constructs, real time visualization, } \\
\text { many variants }\end{array}$ & $\begin{array}{l}\text { Stability (turnover, } \\
\text { photo/pH/temperature stability), } \\
\text { fluorescent tags may affect } \\
\text { tagged protein's function }\end{array}$ & $\begin{array}{l}\text { Hadjantonakis } \\
\text { et al., 2003; Livet } \\
\text { et al., 2007; } \\
\text { Kremers et al., } 2011\end{array}$ \\
\hline & $\begin{array}{l}\text { Genetically- } \\
\text { encoded viral } \\
\text { tracing }\end{array}$ & Rabies & $\begin{array}{l}\text { Neurotropic, retrograde } \\
\text { propagation, may be pseudotyped } \\
\text { for infection selectivity, can reveal } \\
\text { polysynaptic or monosynaptic } \\
\text { connectivity, can be combined } \\
\text { with functional reporters, high } \\
\text { expression }\end{array}$ & $\begin{array}{l}\text { Cytotoxicity (limits experimental } \\
\text { time frame), nascent } \\
\text { anterograde tracing strategies, } \\
\text { can be used in concert with } \\
\text { functional reporters, polysynaptic } \\
\text { tracing cannot distinguish } \\
\text { first-order connectivity }\end{array}$ & $\begin{array}{l}\text { Wickersham et al., } \\
\text { 2007; Wall et al., } \\
\text { 2010; Weible et al., } \\
\text { 2010; Beier et al., } \\
\text { 2011; Osakada } \\
\text { et al., } 2011\end{array}$ \\
\hline & & HSV & $\begin{array}{l}\text { Cre-dependent variants available } \\
\text { for specificity, polysynatpic } \\
\text { tracing, retrograde and } \\
\text { anterograde varieties available }\end{array}$ & $\begin{array}{l}\text { Very high cytotoxicity (limits } \\
\text { experimental time frame) limiting } \\
\text { its use with functional reporters, } \\
\text { polysynaptic tracing cannot } \\
\text { distinguish first-order } \\
\text { connectivity }\end{array}$ & $\begin{array}{l}\text { Kuypers and } \\
\text { Ugolini, 1990; } \\
\text { Zemanick et al., } \\
\text { 1991; Enquist and } \\
\text { Card, 2003; Lo and } \\
\text { Anderson, } 2011\end{array}$ \\
\hline \multirow[t]{7}{*}{ Functional } & $\begin{array}{l}\text { Genetically- } \\
\text { encoded } \\
\text { optogenetics }\end{array}$ & $\begin{array}{l}\text { Excitatory } \\
\text { Channelrhodopsin }\end{array}$ & $\begin{array}{l}\text { Precise temporal control, can be } \\
\text { used to directly assess functional } \\
\text { connectivity, can be used } \\
\text { in vitro/ex vivo/in vivo/awake, } \\
\text { many variants with differential } \\
\text { photo-kinetics }\end{array}$ & $\begin{array}{l}\text { Potential for channel } \\
\text { desensitization or depolarization } \\
\text { block, not always sufficient for } \\
\text { in vivo chronic activation } \\
\text { experiments, physiologically } \\
\text { relevant for excitable cell types } \\
\text { more than for non-excitable cell } \\
\text { types }\end{array}$ & $\begin{array}{l}\text { Zhang et al., 2006; } \\
\text { Mattis et al., 2012; } \\
\text { Hochbaum et al., } \\
2014\end{array}$ \\
\hline & & $\begin{array}{l}\text { Inhibitory } \\
\text { Channelrhodopsin }\end{array}$ & $\begin{array}{l}\text { Precise temporal inhibition, } \\
\text { independent of photon-gated ion } \\
\text { movement, more physiologic }\end{array}$ & Dependence on external pH & $\begin{array}{l}\text { Berndt et al., 2014; } \\
\text { Wietek et al., } 2014\end{array}$ \\
\hline & & Halorhodopsin & Precise temporal inhibition & $\begin{array}{l}\text { Subcellular trafficking issues in } \\
\text { older variants }\end{array}$ & $\begin{array}{l}\text { Gradinaru et al., } \\
2010 \text {; Tye et al., } \\
2011\end{array}$ \\
\hline & & Archaerhodopsin & $\begin{array}{l}\text { Same as for halorhodopsins but } \\
\text { new variants hyperpolarize more, } \\
\text { can be used to manipulate } \mathrm{pH}, \\
\text { can be used as an actuator as } \\
\text { well as an indicator }\end{array}$ & $\begin{array}{l}\text { Limited by proton pump kinetics } \\
\text { often requiring continuous } \\
\text { photostimulation, older variants } \\
\text { dim with long time constants } \\
\text { and photocurrents }\end{array}$ & $\begin{array}{l}\text { Madisen et al., } \\
\text { 2012; Beppu et al., } \\
\text { 2014; Hochbaum } \\
\text { et al., } 2014\end{array}$ \\
\hline & $\begin{array}{l}\text { Genetically- } \\
\text { encoded } \\
\text { chemical } \\
\text { genetics }\end{array}$ & nAchR, TRPV1 & $\begin{array}{l}\text { Endogenous receptor expression } \\
\text { and ligand application to most } \\
\text { faithfully recapitulate neuronal } \\
\text { activation, timescale of activation } \\
\text { within seconds }\end{array}$ & $\begin{array}{l}\text { Unpredictable interactions with } \\
\text { the native ligand-receptor pair, } \\
\text { baseline depolarization in the } \\
\text { absence of ligand }\end{array}$ & $\begin{array}{l}\text { Drenan et al., 2008; } \\
\text { Kim et al., } 2012\end{array}$ \\
\hline & & $\begin{array}{l}\text { Interspecies } \\
\text { channel proteins } \\
\text { or GPCRs }\end{array}$ & Ligand-receptor selectivity & $\begin{array}{l}\text { G-protein-coupled receptor } \\
\text { off-target effects, ligand usually } \\
\text { does not cross blood-brain } \\
\text { barrier and thus must be applied } \\
\text { locally using invasive procedures }\end{array}$ & $\begin{array}{l}\text { Lechner et al., } \\
2002 \text {; Slimko et al., } \\
2002\end{array}$ \\
\hline & & GABAA & $\begin{array}{l}\text { Single modified endogenous } \\
\text { GABAA receptor can be agonized } \\
\text { and antagonized by different } \\
\text { ligands (zolpidem, DMCM, } \\
\text { respectively) }\end{array}$ & $\begin{array}{l}\text { Requires a } \\
\text { genetically-engineered } \\
\text { zolpidem-insensitive background }\end{array}$ & Wulff et al., 2007 \\
\hline
\end{tabular}




\begin{tabular}{|c|c|c|c|c|}
\hline & & Strengths & Challenges & References \\
\hline & PSEM & $\begin{array}{l}\text { Ligand-receptor selectivity, are not } \\
\text { GPCR-based and thus minimize } \\
\text { G-protein-coupled off-target effects, } \\
\text { non-invasive ligand administration }\end{array}$ & $\begin{array}{l}\text { May not be adequate for sustained } \\
\text { activation/inhibition over prolonged } \\
\text { periods compared to other methods } \\
\text { (e.g., DREADDs). }\end{array}$ & $\begin{array}{l}\text { Magnus et al., 2011; } \\
\text { Sternson and Roth, } \\
2014\end{array}$ \\
\hline & DREADD & $\begin{array}{l}\text { Minute-hour activation/inhibition, } \\
\text { manipulates excitable and } \\
\text { non-excitable cells, recapitulates } \\
\text { dysfunction in disease, non-invasive } \\
\text { ligand administration }\end{array}$ & $\begin{array}{l}\text { G-protein-coupled receptor off-target } \\
\text { effects, requires different receptors } \\
\text { for activation versus inhibition }\end{array}$ & $\begin{array}{l}\text { Ferguson et al., } \\
\text { 2011; Krashes et al., } \\
\text { 2011; Ray et al., } \\
\text { 2011; Wulff and } \\
\text { Arenkiel, 2012; } \\
\text { Wess et al., } 2013\end{array}$ \\
\hline \multirow[t]{4}{*}{$\begin{array}{l}\text { Genetically- } \\
\text { encoded } \\
\text { molecular imaging }\end{array}$} & GCAMP & $\begin{array}{l}\text { In vivo imaging of neuronal activity, } \\
\text { continually re-engineered for } \\
\text { improved signal to noise }\end{array}$ & $\begin{array}{l}\text { Limited dynamic range, indirect } \\
\text { measure of action potentials, cannot } \\
\text { parse resting from tonic activity, } \\
\text { trade-off between } \mathrm{Ca}^{2+} \text {-binding } \\
\text { affinity and response }\end{array}$ & Tian et al., 2009 \\
\hline & $\begin{array}{l}\text { Twitch } \\
\text { (FRET-based) }\end{array}$ & $\begin{array}{l}\text { More stable long-term in vivo } \\
\text { imaging, brighter, subcellular } \\
\text { visualization, differentiates resting } \\
\text { state } \mathrm{Ca}^{2+} \text { from tonic firing, large } \\
\text { dynamic range, linear responses }\end{array}$ & $\begin{array}{l}\text { Indirect measure of action } \\
\text { potentials, trade-off between high } \\
\text { calcium binding affinity and } \\
\text { response kinetics. }\end{array}$ & Thestrup et al., 2014 \\
\hline & $\begin{array}{l}\text { Clomeleon } \\
\text { (FRET-based) }\end{array}$ & $\begin{array}{l}\text { Can be used to study developmental } \\
\text { neuronal changes in } \mathrm{Cl}^{-} \text {as well as } \\
\text { network effects of GABA activity }\end{array}$ & $\begin{array}{l}\text { Lower affinity }(\sim 30 \mathrm{mM}) \text { compared } \\
\text { to the intracellular } \mathrm{Cl}^{-} \text {concentration } \\
(\sim 10 \mathrm{mM}) \text {; } \mathrm{pH} \text { sensitive, } \\
\text { photobleach at different rates, } \\
\text { interfering with FRET signal }\end{array}$ & $\begin{array}{l}\text { Kuner and } \\
\text { Augustine, 2000; } \\
\text { Glykys et al., } 2014\end{array}$ \\
\hline & SynaptopHluorin & $\begin{array}{l}\text { Measures the release of } \\
\text { neurotransmitters }\end{array}$ & Diffusional loss of the reporter & $\begin{array}{l}\text { Granseth et al., } \\
2006\end{array}$ \\
\hline
\end{tabular}

Given the timescale at which optogenetic reporters function, they are appropriate for manipulating rapid, time-sensitive circuit properties that influence behaviors. However, for behaviors or disease states that require changes in activity to persist over longer intervals, chronic photic activation or inhibition of neurons can be technically cumbersome and even deleterious to the cells under investigation. If the scientific question requires persistent activity manipulation in a population of neurons to influence behaviors occurring over larger timescales, pharmacologically-activated designer receptors offer an alternative approach (Wulff and Arenkiel, 2012). Transgenic overexpression of an endogenous ionic receptor can be modulated by application of its ligand to produce membrane depolarization (Drenan et al., 2008; Kim et al., 2012), but interactions with the native ligand-receptor pair might unpredictably influence experimental outcomes. Chemically and genetically engineered ligand gated ion channels (Wulff et al., 2007) insensitive to endogenous ligands (Wulff et al., 2007; Magnus et al., 2011; Sternson and Roth, 2014), or mammalian expression of channel proteins or excitatory or inhibitory G protein-coupled receptors (GPCRs) from invertebrates (Lechner et al., 2002; Slimko et al., 2002) strategically attempt to avoid this confound, but engineered GPCRs offer perhaps the most elegant alternative (Armbruster et al., 2007). A recent incarnation of these is the DREADDs (designer receptors exclusively activated by designer drugs) (Armbruster et al., 2007), which employ an engineered receptor-synthetic ligand pair that is completely orthogonal to its endogenous equivalent, exhibits little or no baseline activity, and allows for genetically targeted activation or inhibition (Ferguson et al., 2011; Krashes et al., 2011; Ray et al., 2011). GPCRs mediate intracellular signaling cascades activated by various monoaminergic neurotransmitters and neuropeptides, more faithfully recapitulating the postsynaptic changes that may ensue with activation or inhibition of interneuronal cell types. As many neuropsychiatric disorders are the result of dysfunction or loss of these interneurons, designer GPCRs may also generate conditions that most resemble disease states. Furthermore, they offer the unique advantage of functionally dissecting intact deep subcortical circuits in a way that is more difficult or not possible with optogenetic and imaging methods used readily at the cortical surface. In order to study the complex compensatory changes that may occur with chronic, irreversible cell type-specific loss, we can employ genetically targeted lesions (Buch et al., 2005). Both reversible ligandmediated methods and genetic lesions offer the advantage of being minimally invasive, and require only viral delivery of a receptor and peripheral application of its cognate ligand. These techniques can also be used concurrently with electrophysiological recordings without introducing overt artifacts, though a 
remarkable new alternative enables cross-talk free all-optogenetic actuation and indication using genetically modified channelrhodopsins and archaerhodopsins (Hochbaum et al., 2014) as well.

Genetically encoded molecular indicators augment the information that is available through traditional electrophysiological and behavioral assays of circuit function. These biosensors come in many varieties; briefly discussed here are fluorescent indicators for calcium, chloride, and neurotransmitter vesicular release. Calcium biosensors come in two forms-single wavelength sensors and ratiometric sensors that rely on fluorescence energy resonance transfer (FRET). GCaMP, an example of the former, is a fusion of GFP with calmodulin, an intracellular protein that binds calcium. In the presence of calcium, calmodulin undergoes a conformational change, which renders the GFP brighter than at baseline (Tian et al., 2009), thus allowing the detection of increased neuronal activity that occurs with calcium entry. This tool fundamentally relies on measurements of relative fluorescence. FRET allows for more stable and high resolution long term imaging, which can be used to study the neuromodulatory role of interneurons in fluctuating brain states as well as subcellular localization of GPCR signaling (protein kinase A) by neuromodulators (Chen et al., 2014). Interneurons tend to have characteristic projections onto the soma, dendrites, and axons of postsynaptic target cells, subcellular compartments that can be resolved by this technique. Ratiometric measurements can also differentiate resting state $\mathrm{Ca}^{2+}$ from $\mathrm{Ca}^{2+}$ influx of tonically firing neurons, a property that also segregates differentially between and within interneuronal classes. While calcium indicators have been especially useful to study neuronal activity (Thestrup et al., 2014), this reflects only the spiking behavior of the interneurons rather than their network level inhibitory outputs. A complementary approach to study inhibition takes advantage of the genetically encoded fluorescent chloride indicator, clomeleon (Kuner and Augustine, 2000). Clomeleon can be used to study network effects of GABA activity, and uniquely, developmental neuronal changes in $\mathrm{Cl}^{-}$to report neuronal inhibition. Finally, synaptopHluorin is a genetically encoded neurotransmitter indicator engineered as a fusion between synapsin, a presynaptic vesicular fusion protein, and a $\mathrm{pH}$ sensitive GFP. In an acidic environment of synaptic vesicles prior to release, the GFP does not fluoresce. Alkalinization of the vesicles upon release into the extracellular space with neuronal activity results in bright fluorescence. Together, each of these neuroimaging tools allows for insight into the circuit connectivity of interneurons.

\section{CONCLUSIONS AND DIRECTIONS FOR FUTURE RESEARCH}

Interneurons exhibit heterogeneous origins, morphologies, and functions that render their detailed characterization challenging. We advocate for an intersectional dissection of this heterogeneity. Starting with genetic and molecular tools (Table 2), we can characterize cardinal groups of interneurons that we further parse with powerful new techniques such as single cell gene expression analyses (Kamme et al., 2003) to elaborate iteratively what molecules better define classes. Though we did not expand on functionally characterizing interneurons with an eye to their role in specific behaviors (Kvitsiani et al., 2013; Courtin et al., 2014) and their dysfunction/attrition in disease (Verret et al., 2012;
Benarroch, 2013; Del Pino et al., 2013), this may also help to constrain their undeniably vast genetic and molecular diversity. As interneuron classes are delimited operationally, and dynamically refined using genetically targeted methods, answers emerge about the shared molecular features of specific neuronal subsets that can then be exploited to generate targeted genetic approaches to their further study.

\section{ACKNOWLEDGMENTS}

We would like to thank Kathleen Quast for her input on the manuscript. This was supported by T32NS043124 to Dona K. Murphey and NS078294 to Benjamin R. Arenkiel.

\section{REFERENCES}

Armbruster, B. N., Li, X., Pausch, M. H., Herlitze, S., and Roth, B. L. (2007). Evolving the lock to fit the key to create a family of $\mathrm{G}$ protein-coupled receptors potently activated by an inert ligand. Proc. Natl. Acad. Sci. U.S.A. 104, 5163-5168. doi: 10.1073/pnas.0700293104

Ascoli, G. A., Alonso-Nanclares, L., Anderson, S. A., Barrionuevo, G., BenavidesPiccione, R., Burkhalter, A., et al. (2008). Petilla terminology: nomenclature of features of GABAergic interneurons of the cerebral cortex. Nat. Rev. Neurosci. 9 , 557-568. doi: 10.1038/nrn2402

Beier, K. T., Saunders, A., Oldenburg, I. A., Miyamichi, K., Akhtar, N., Luo, L., et al. (2011). Anterograde or retrograde transsynaptic labeling of CNS neurons with vesicular stomatitis virus vectors. Proc. Natl. Acad. Sci. U.S.A. 108, 15414-15419. doi: $10.1073 /$ pnas. 1110854108

Benarroch, E. E. (2013). Neocortical interneurons: functional diversity and clinical correlations. Neurology 81, 273-280. doi: 10.1212/WNL.0b013e31829c002f

Beppu, K., Sasaki, T., Tanaka, K. F., Yamanaka, A., Fukazawa, Y., Shigemoto, R., et al. (2014). Optogenetic countering of glial acidosis suppresses glial glutamate release and ischemic brain damage. Neuron 81, 314-320. doi: 10.1016/j.neuron.2013.11.011

Berndt, A., Lee, S. Y., Ramakrishnan, C., and Deisseroth, K. (2014). Structureguided transformation of channelrhodopsin into a light-activated chloride channel. Science 344, 420-424. doi: 10.1126/science.1252367

Betley, J. N., and Sternson, S. M. (2011). Adeno-associated viral vectors for mapping, monitoring, and manipulating neural circuits. Hum. Gene Ther. 22, 669-677. doi: 10.1089/hum.2010.204

Brown, J., Pan, W. X., and Dudman, J. T. (2014). The inhibitory microcircuit of the substantia nigra provides feedback gain control of the basal ganglia output. eLife 3:e02397. doi: 10.7554/eLife.02397

Buch, T., Heppner, F. L., Tertilt, C., Heinen, T. J., Kremer, M., Wunderlich, F. T., et al. (2005). A Cre-inducible diphtheria toxin receptor mediates cell lineage ablation after toxin administration. Nat. Methods 2, 419-426. doi: 10.1038/nmeth762

Buzsaki, G., Geisler, C., Henze, D. A., and Wang, X. J. (2004). Interneuron Diversity series: circuit complexity and axon wiring economy of cortical interneurons. Trends Neurosci. 27, 186-193. doi: 10.1016/j.tins.2004.02.007

Caputi, A., Melzer, S., Michael, M., and Monyer, H. (2013). The long and short of GABAergic neurons. Curr. Opin. Neurobiol. 23, 179-186. doi: 10.1016/j.conb.2013.01.021

Chattopadhyaya, B., Di Cristo, G., Wu, C. Z., Knott, G., Kuhlman, S., Fu, Y., et al. (2007). GAD67-mediated GABA synthesis and signaling regulate inhibitory synaptic innervation in the visual cortex. Neuron 54, 889-903. doi: 10.1016/j.neuron.2007.05.015

Chen, Y., Saulnier, J. L., Yellen, G., and Sabatini, B. L. (2014). A PKA activity sensor for quantitative analysis of endogenous GPCR signaling via 2-photon FRETFLIM imaging. Front. Pharmacol. 5:56. doi: 10.3389/fphar.2014.00056

Chiovini, B., Turi, G. F., Katona, G., Kaszás, A., Pálfi, D., Maák, P., et al. (2014). Dendritic spikes induce ripples in parvalbumin interneurons during hippocampal sharp waves. Neuron 82, 908-924. doi: 10.1016/j.neuron.2014.04.004

Chittajallu, R., Craig, M. T., McFarland, A., Yuan, X., Gerfen, S., Tricoire, L., et al. (2013). Dual origins of functionally distinct O-LM interneurons revealed by differential 5-HT(3A)R expression. Nat. Neurosci. 16, 1598-1607. doi: 10.1038/nn.3538

Chiu, C. Q., Lur, G., Morse, T. M., Carnevale, N. T., Ellis-Davies, G. C., and Higley, M. J. (2013). Compartmentalization of GABAergic inhibition by dendritic spines. Science 340, 759-762. doi: 10.1126/science.1234274 
Cho, K., and Sohal, V. S. (2014). Optogenetic approaches for investigating neural pathways implicated in schizophrenia and related disorders. Hum. Mol. Genet. 23, R64-R68. doi: 10.1093/hmg/ddu225

Courtin, J., Chaudun, F., Rozeske, R. R., Karalis, N., Gonzalez-Campo, C., Wurtz, H., et al. (2014). Prefrontal parvalbumin interneurons shape neuronal activity to drive fear expression. Nature 505, 92-96. doi: 10.1038/nature12755

Del Pino, I., Garcia-Frigola, C., Dehorter, N., Brotons-Mas, J. R., AlvarezSalvado, E., de Lagrán, M. M., et al. (2013). Erbb4 deletion from fast-spiking interneurons causes schizophrenia-like phenotypes. Neuron 79, 1152-1168. doi: 10.1016/j.neuron.2013.07.010

Drenan, R. M., Grady, S. R., Whiteaker, P., McClure-Begley, T., McKinney, S., Miwa, J. M., et al. (2008). In vivo activation of midbrain dopamine neurons via sensitized, high-affinity alpha 6 nicotinic acetylcholine receptors. Neuron 60 , 123-136. doi: 10.1016/j.neuron.2008.09.009

Dymecki, S. M., and Kim, J. C. (2007). Molecular neuroanatomy's “Three Gs”: a primer. Neuron 54, 17-34. doi: 10.1016/j.neuron.2007.03.009

Enquist, L. W., and Card, J. P. (2003). Recent advances in the use of neurotropic viruses for circuit analysis. Curr. Opin. Neurobiol. 13, 603-606. doi: 10.1016/j.conb.2003.08.001

Ferguson, S. M., Eskenazi, D., Ishikawa, M., Wanat, M. J., Phillips, P. E., Dong, Y., et al. (2011). Transient neuronal inhibition reveals opposing roles of indirect and direct pathways in sensitization. Nat. Neurosci. 14, 22-24. doi: 10.1038/nn. 2703

Fu, Y., Tucciarone, J. M., Espinosa, J. S., Sheng, N., Darcy, D. P., Nicoll, R. A., et al. (2014). A cortical circuit for gain control by behavioral state. Cell 156, 1139-1152. doi: 10.1016/j.cell.2014.01.050

Garcia-Otin, A. L., and Guillou, F. (2006). Mammalian genome targeting using sitespecific recombinases. Front. Biosci. 11, 1108-1136. doi: 10.2741/1867

Gernert, M., Bennay, M., Fedrowitz, M., Rehders, J. H., and Richter, A. (2002). Altered discharge pattern of basal ganglia output neurons in an animal model of idiopathic dystonia. J. Neurosci. 22, 7244-7253.

Gernert, M., Hamann, M., Bennay, M., Löscher, W., and Richter, A. (2000). Deficit of striatal parvalbumin-reactive GABAergic interneurons and decreased basal ganglia output in a genetic rodent model of idiopathic paroxysmal dystonia. J. Neurosci. 20, 7052-7058.

Gittis, A. H., Leventhal, D. K., Fensterheim, B. A., Pettibone, J. R., Berke, J. D., and Kreitzer, A. C. (2011). Selective inhibition of striatal fastspiking interneurons causes dyskinesias. J. Neurosci. 31, 15727-15731. doi: 10.1523/JNEUROSCI.3875-11.2011

Glykys, J., Dzhala, V., Egawa, K., Balena, T., Saponjian, Y., Kuchibhotla, K. V., et al. (2014). Local impermeant anions establish the neuronal chloride concentration. Science 343, 670-675. doi: 10.1126/science. 1245423

Gradinaru, V., Mogri, M., Thompson, K. R., Henderson, J. M., and Deisseroth, K. (2009). Optical deconstruction of parkinsonian neural circuitry. Science 324, 354-359. doi: 10.1126/science. 1167093

Gradinaru, V., Thompson, K. R., and Deisseroth, K. (2008). eNpHR: a Natronomonas halorhodopsin enhanced for optogenetic applications. Brain Cell Biol. 36, 129-139. doi: 10.1007/s11068-008-9027-6

Gradinaru, V., Zhang, F., Ramakrishnan, C., Mattis, J., Prakash, R., Diester, I., et al. (2010). Molecular and cellular approaches for diversifying and extending optogenetics. Cell 141, 154-165. doi: 10.1016/j.cell.2010.02.037

Granseth, B., Odermatt, B., Royle, S. J., and Lagnado, L. (2006). Clathrin-mediated endocytosis is the dominant mechanism of vesicle retrieval at hippocampal synapses. Neuron 51, 773-786. doi: 10.1016/j.neuron.2006.08.029

Gyurko, R., Leupen, S., and Huang, P. L. (2002). Deletion of exon 6 of the neuronal nitric oxide synthase gene in mice results in hypogonadism and infertility. Endocrinology 143, 2767-2774. doi: 10.1210/endo.143.7.8921

Hadjantonakis, A. K., Dickinson, M. E., Fraser, S. E., and Papaioannou, V. E. (2003). Technicolour transgenics: imaging tools for functional genomics in the mouse. Nat. Rev. Genetics 4, 613-625. doi: 10.1038/nrg1126

Halassa, M. M., Chen, Z., Wimmer, R. D., Brunetti, P. M., Zhao, S., Zikopoulos, B., et al. (2014). State-dependent architecture of thalamic reticular subnetworks. Cell 158, 808-821. doi: 10.1016/j.cell.2014.06.025

Hamilton, L. S., Sohl-Dickstein, J., Huth, A. G., Carels, V. M., Deisseroth, K., and Bao, S. (2013). Optogenetic activation of an inhibitory network enhances feedforward functional connectivity in auditory cortex. Neuron 80, 1066-1076. doi: 10.1016/j.neuron.2013.08.017

Heintz, N. (2001). BAC to the future: the use of bac transgenic mice for neuroscience research. Nat. Rev. Neurosci. 2, 861-870. doi: 10.1038/35104049
Herman, A. M., Huang, L., Murphey, D. K., Garcia, I., and Arenkiel, B. R. (2014). Cell type-specific and time-dependent light exposure contribute to silencing in neurons expressing Channelrhodopsin-2. eLife 3:e01481. doi: 10.7554/eLife.01481

Hioki, H., Okamoto, S., Konno, M., Kameda, H., Sohn, J., Kuramoto, E., et al. (2013). Cell type-specific inhibitory inputs to dendritic and somatic compartments of parvalbumin-expressing neocortical interneuron. J. Neurosci. 33, 544-555. doi: 10.1523/JNEUROSCI.2255-12.2013

Hochbaum, D. R., Zhao, Y., Farhi, S. L., Klapoetke, N., Werley, C. A., Kapoor, V., et al. (2014). All-optical electrophysiology in mammalian neurons using engineered microbial rhodopsins. Nat. Methods 11, 825-833. doi: 10.1038/nmeth. 3000

Hodgson, L., Pertz, O., and Hahn, K. M. (2008). Design and optimization of genetically encoded fluorescent biosensors: GTPase biosensors. Methods Cell Biol. 85, 63-81. doi: 10.1016/S0091-679X(08)85004-2

Huang, L., Garcia, I., Jen, H. I., and Arenkiel, B. R. (2013). Reciprocal connectivity between mitral cells and external plexiform layer interneurons in the mouse olfactory bulb. Front. Neural Circuits 7:32. doi: 10.3389/fncir.2013. 00032

Jennings, J. H., Rizzi, G., Stamatakis, A. M., Ung, R. L., and Stuber, G. D. (2013). The inhibitory circuit architecture of the lateral hypothalamus orchestrates feeding. Science 341, 1517-1521. doi: 10.1126/science.1241812

Kalanithi, P. S., Zheng, W., Kataoka, Y., DiFiglia, M., Grantz, H., Saper, C. B., et al. (2005). Altered parvalbumin-positive neuron distribution in basal ganglia of individuals with Tourette syndrome. Proc. Natl. Acad. Sci. U.S.A. 102, 13307-13312. doi: 10.1073/pnas.0502624102

Kamme, F., Salunga, R., Yu, J., Tran, D. T., Zhu, J., Luo, L., et al. (2003). Singlecell microarray analysis in hippocampus CA1: demonstration and validation of cellular heterogeneity. J. Neurosci. 23, 3607-3615.

Kataoka, Y., Kalanithi, P. S., Grantz, H., Schwartz, M. L., Saper, C., Leckman, J. F., et al. (2010). Decreased number of parvalbumin and cholinergic interneurons in the striatum of individuals with Tourette syndrome. J. Comp. Neurol. 518, 277-291. doi: 10.1002/cne.22206

Kato, H. K., Gillet, S. N., Peters, A. J., Isaacson, J. S., and Komiyama, T. (2013). Parvalbumin-expressing interneurons linearly control olfactory bulb output. Neuron 80, 1218-1231. doi: 10.1016/j.neuron.2013.08.036

Kepecs, A., and Fishell, G. (2014). Interneuron cell types are fit to function. Nature 505, 318-326. doi: 10.1038/nature 12983

Kerr, B. J., Cafferty, W. B., Gupta, Y. K., Bacon, A., Wynick, D., McMahon, S. B., et al. (2000). Galanin knockout mice reveal nociceptive deficits following peripheral nerve injury. Eur. J. Neurosci. 12, 793-802. doi: 10.1046/j.14609568.2000.00967.x

Kim, E. H., Thu, D. C., Tippett, L. J., Oorschot, D. E., Hogg, V. M., Roxburgh, R., et al. (2014). Cortical interneuron loss and symptom heterogeneity in Huntington disease. Ann. Neurol. 75, 717-727. doi: 10.1002/ana. 24162

Kim, Y. H., Back, S. K., Davies, A. J., Jeong, H., Jo, H. J., Chung, G., et al. (2012). TRPV1 in GABAergic interneurons mediates neuropathic mechanical allodynia and disinhibition of the nociceptive circuitry in the spinal cord. Neuron 74, 640-647. doi: 10.1016/j.neuron.2012.02.039

Kimura, S., Hara, Y., Pineau, T., Fernandez-Salguero, P., Fox, C. H., Ward, J. M., et al. (1996). The T/ebp null mouse: thyroid-specific enhancer-binding protein is essential for the organogenesis of the thyroid, lung, ventral forebrain, and pituitary. Genes Dev. 10, 60-69. doi: 10.1101/gad.10.1.60

Krashes, M. J., Koda, S., Ye, C., Rogan, S. C., Adams, A. C., Cusher, D. S., et al. (2011). Rapid, reversible activation of AgRP neurons drives feeding behavior in mice. J. Clin. Invest. 121, 1424-1428. doi: 10.1172/JCI46229

Kravitz, A. V., Freeze, B. S., Parker, P. R. L., Kay, K., Thwin, M. T., Deisseroth, K., et al. (2010). Regulation of parkinsonian motor behaviours by optogenetic control of basal ganglia circuitry. Nature 466, 622-626. doi: 10.1038/nature09159

Kravitz, A. V., Tye, L. D., and, and Kreitzer, A. C. (2012). Distinct roles for direct and indirect pathway striatal neurons in reinforcement. Nat. Neurosci. 15, 816-818. doi: $10.1038 / \mathrm{nn} .3100$

Kremers, G. J., Gilbert, S. G., Cranfill, P. J., Davidson, M. W., and Piston, D. W. (2011). Fluorescent proteins at a glance. J. Cell Sci. 124(Pt 2), 157-160. doi: $10.1242 /$ jcs.072744

Krook-Magnuson, E., Armstrong, C., Oijala, M., and Soltesz, I. (2013). On-demand optogenetic control of spontaneous seizures in temporal lobe epilepsy. Nat. Commun. 4:1376. doi: 10.1038/ncomms2376 
Kuhlman, S. J., Olivas, N. D., Tring, E., Ikrar, T., Xu, X., and Trachtenberg, J. T. (2013). A disinhibitory microcircuit initiates critical-period plasticity in the visual cortex. Nature 501, 543-546. doi: 10.1038/nature12485

Kumar, A., Vlachos, I., Aertsen, A., and Boucsein, C. (2013). Challenges of understanding brain function by selective modulation of neuronal subpopulations. Trends Neurosci. 36, 579-586. doi: 10.1016/j.tins.2013.06.005

Kuner, T., and Augustine, G. J. (2000). A genetically encoded ratiometric indicator for chloride: capturing chloride transients in cultured hippocampal neurons. Neuron 27, 447-459. doi: 10.1016/S0896-6273(00)00056-8

Kusakabe, T., Kawaguchi, A., Hoshi, N., Kawaguchi, R., Hoshi, S., and Kimura, S. (2006). Thyroid-specific enhancer-binding protein/NKX2.1 is required for the maintenance of ordered architecture and function of the differentiated thyroid. Mol. Endocrinol. 20, 1796-1809. doi: 10.1210/me.2005-0327

Kuypers, H. G., and Ugolini, G. (1990). Viruses as transneuronal tracers. Trends Neurosci. 13, 71-75. doi: 10.1016/0166-2236(90)90071-H

Kvitsiani, D., Ranade, S., Hangya, B., Taniguchi, H., Huang, J. Z., and Kepecs, A. (2013). Distinct behavioural and network correlates of two interneuron types in prefrontal cortex. Nature 498, 363-366. doi: 10.1038/nature12176

Lapray, D., Lasztoczi, B., Lagler, M., Viney, T. J., Katona, L., Valenti, O., et al. (2012). Behavior-dependent specialization of identified hippocampal interneurons. Nat. Neurosci. 15, 1265-1271. doi: 10.1038/nn.3176

Lechner, H. A., Lein, E. S., and Callaway, E. M. (2002). A genetic method for selective and quickly reversible silencing of Mammalian neurons. J. Neurosci. 22, 5287-5290.

Ledri, M., Madsen, M. G., Nikitidou, L., Kirik, D., and Kokaia, M. (2014). Global optogenetic activation of inhibitory interneurons during epileptiform activity. J. Neurosci. 34, 3364-3377. doi: 10.1523/JNEUROSCI.2734-13.2014

Lee, S. H., Kwan, A. C., and Dan, Y. (2014). Interneuron subtypes and orientation tuning. Nature 508, E1-E2. doi: 10.1038/nature13128

Lee, S. H., Kwan, A. C., Zhang, S., Phoumthipphavong, V., Flannery, J. G., Masmanidis, S. C., et al. (2012). Activation of specific interneurons improves V1 feature selectivity and visual perception. Nature 488, 379-383. doi: 10.1038 /nature 11312

Lee, S., Kruglikov, I., Huang, Z. J., Fishell, G., and Rudy, B. (2013). A disinhibitory circuit mediates motor integration in the somatosensory cortex. Nat. Neurosci. 16, 1662-1670. doi: 10.1038/nn.3544

Letzkus, J. J., Wolff, S. B., Meyer, E. M., Tovote, P., Courtin, J., Herry, C., et al. (2011). A disinhibitory microcircuit for associative fear learning in the auditory cortex. Nature 480, 331-335. doi: 10.1038/nature10674

Liodis, P., Denaxa, M., Grigoriou, M., Akufo-Addo, C., Yanagawa, Y., and Pachnis, V. (2007). Lhx6 activity is required for the normal migration and specification of cortical interneuron subtypes. J. Neurosci. 27, 3078-3089. doi: 10.1523/JNEUROSCI.3055-06.2007

Livet, J., Weissman, T. A., Kang, H., Draft, R. W., Lu, J., Bennis, R. A., et al. (2007). Transgenic strategies for combinatorial expression of fluorescent proteins in the nervous system. Nature 450, 56-62. doi: 10.1038/nature06293

Lo, L., and Anderson, D. J. (2011). A Cre-dependent, anterograde transsynaptic viral tracer for mapping output pathways of genetically marked neurons. Neuron 72, 938-950. doi: 10.1016/j.neuron.2011.12.002

Luo, L., Callaway, E. M., and Svoboda, K. (2008). Genetic dissection of neural circuits. Neuron 57, 634-660. doi: 10.1016/j.neuron.2008.01.002

Ma, Y., Hu, H., Berrebi, A. S., Mathers, P. H., and Agmon, A. (2006). Distinct subtypes of somatostatin-containing neocortical interneurons revealed in transgenic mice. J. Neurosci. 26, 5069-5082. doi: 10.1523/JNEUROSCI.066106.2006

Madisen, L., Mao, T., Koch, H., Zhuo, J. M., Berenyi, A., Fujisawa, S., et al. (2012). A toolbox of Cre-dependent optogenetic transgenic mice for lightinduced activation and silencing. Nat. Neurosci. 15, 793-802. doi: 10.1038/ nn. 3078

Magnus, C. J., Lee, P. H., Atasoy, D., Su, H. H., Looger, L. L., and Sternson, S. M. (2011). Chemical and genetic engineering of selective ion channel-ligand interactions. Science 333, 1292-1296. doi: 10.1126/science.1206606

Markram, H., Toledo-Rodriguez, M., Wang, Y., Gupta, A., Silberberg, G., and Wu, C. (2004). Interneurons of the neocortical inhibitory system. Nat. Rev. Neurosci. 5, 793-807. doi: 10.1038/nrn1519

Mattis, J., Tye, K. M., Ferenczi, E. A., Ramakrishnan, C., O’Shea, D. J., Prakash, R., et al. (2012). Principles for applying optogenetic tools derived from direct comparative analysis of microbial opsins. Nat. Methods 9, 159-172. doi: 10.1038/nmeth. 1808
Melzer, S., Michael, M., Caputi, A., Eliava, M., Fuchs, E. C., Whittington, M. A., et al. (2012). Long-range-projecting GABAergic neurons modulate inhibition in hippocampus and entorhinal cortex. Science 335, 1506-1510. doi: 10.1126/science.1217139

Misgeld, T., Burgess, R. W., Lewis, R. M., Cunningham, J. M., Lichtman, J. W., and Sanes, J. R. (2002). Roles of neurotransmitter in synapse formation: development of neuromuscular junctions lacking choline acetyltransferase. Neuron 36, 635-648. doi: 10.1016/S0896-6273(02)01020-6

Miyoshi, G., Hjerling-Leffler, J., Karayannis, T., Sousa, V. H., Butt, S. J. B., Battiste, J., et al. (2010). Genetic fate mapping reveals that the caudal ganglionic eminence produces a large and diverse population of superficial cortical interneurons. J. Neurosci. 30, 1582-1594. doi: 10.1523/JNEUROSCI.4515-09.2010

Nassel, D. R. (1993). Neuropeptides in the insect brain: a review. Cell Tissue Res. 273, 1-29. doi: 10.1007/BF00304608

Nathanson, J. L., Jappelli, R., Scheeff, E. D., Manning, G., Obata, K., Brenner, S., et al. (2009). Short promoters in viral vectors drive selective expression in mammalian inhibitory neurons, but do not restrict activity to specific inhibitory cell-types. Front. Neural Circuits 3:19. doi: 10.3389/neuro.04.019.2009

Nelson, A. B., Hammack, N., Yang, C. F., Shah, N. M., Seal, R. P., Kreitzer, A. C., et al. (2014). Striatal cholinergic interneurons Drive GABA release from dopamine terminals. Neuron 82, 63-70. doi: 10.1016/j.neuron.2014.01.023

Osakada, F., Mori, T., Cetin, A. H., Marshel, J. H., Virgen, B., and Callaway, E. M. (2011). New rabies virus variants for monitoring and manipulating activity and gene expression in defined neural circuits. Neuron 71, 617-631. doi 10.1016/j.neuron.2011.07.005

Peng, Z., Zhang, N., Wei, W., Huang, C. S., Cetina, Y., Otis, T. S., et al. (2013). A reorganized GABAergic circuit in a model of epilepsy: evidence from optogenetic labeling and stimulation of somatostatin interneurons. J. Neurosci. 33, 14392-14405. doi: 10.1523/JNEUROSCI.2045-13.2013

Petryszyn, S., Beaulieu, J. M., Parent, A., and Parent, M. (2014). Distribution and morphological characteristics of striatal interneurons expressing calretinin in mice: a comparison with human and nonhuman primates. J. Chem. Neuroanat. 59-60, 51-61. doi: 10.1016/j.jchemneu.2014.06.002

Pfeffer, C. K., Xue, M., He, M., Huang, Z. J., and Scanziani, M. (2013). Inhibition of inhibition in visual cortex: the logic of connections between molecularly distinct interneurons. Nat. Neurosci. 16, 1068-1076. doi: 10.1038/nn.3446

Pi, H. J., Hangya, B., Kvitsiani, D., Sanders, J. I., Huang, Z. J., and Kepecs, A. (2013). Cortical interneurons that specialize in disinhibitory control. Nature 503, 521-524. doi: 10.1038/nature 12676

Povysheva, N. V., Zaitsev, A. V., Gonzalez-Burgos, G., and Lewis, D. A. (2013). Electrophysiological heterogeneity of fast-spiking interneurons: chandelier versus basket cells. PLoS ONE 8:e70553. doi: 10.1371/journal.pone.0070553

Qian, S., Chen, H., Weingarth, D., Trumbauer, M. E., Novi, D. E., Guan, X., et al. (2002). Neither agouti-related protein nor neuropeptide $Y$ is critically required for the regulation of energy homeostasis in mice. Mol. Cell. Biol. 22, 5027-5035. doi: 10.1128/MCB.22.14.5027-5035.2002

Qiu, M., Bulfone, A., Ghattasa, I., Menesesb, J. J., Christensenc, L., Sharpe, P. T., et al. (1997). Role of the Dlx homeobox genes in proximodistal patterning of the branchial arches: mutations of Dlx-1, Dlx-2, and Dlx-1 and -2 alter morphogenesis of proximal skeletal and soft tissue structures derived from the first and second arches. Dev. Biol. 185, 165-184. doi: 10.1006/dbio.1997.8556

Ray, R. S., Corcoran, A. E., Brust, R. D., Kim, J. C., Richerson, G. B., Nattie, E., et al. (2011). Impaired respiratory and body temperature control upon acute serotonergic neuron inhibition. Science 333, 637-642. doi: 10.1126/science. 1205295

Robledo, R. F., Rajan, L., Li, X., and Lufkin, T. (2002). The Dlx5 and Dlx6 homeobox genes are essential for craniofacial, axial, and appendicular skeletal development. Genes Dev. 16, 1089-1101. doi: 10.1101/gad.988402

Rothermel, M., Brunert, D., Zabawa, C., Díaz-Quesada, M., and Wachowiak, M. (2013). Transgene expression in target-defined neuron populations mediated by retrograde infection with adeno-associated viral vectors. J. Neurosci. 33, 15195-15206. doi: 10.1523/JNEUROSCI.1618-13.2013

Roux, L., Stark, E., Sjulson, L., and Buzsáki, G. (2014). In vivo optogenetic identification and manipulation of GABAergic interneuron subtypes. Curr. Opin. Neurobiol. 26C, 88-95. doi: 10.1016/j.conb.2013.12.013

Rudy, B., Fishell, G., Lee, S., and Hjerling-Leffler, J. (2011). Three groups of interneurons account for nearly $100 \%$ of neocortical GABAergic neurons. Dev. Neurobiol. 71, 45-61. doi: 10.1002/dneu.20853

Runyan, C. A., Schummers, J., Van Wart, A., Kuhlman, S. J., Wilson, N. R., Huang, Z. J., et al. (2010). Response features of parvalbumin-expressing interneurons 
suggest precise roles for subtypes of inhibition in visual cortex. Neuron 67, 847-857. doi: 10.1016/j.neuron.2010.08.006

Schnutgen, F., Doerflinger, N., Calléja, C., Wendling, O., Chambon, P., and Ghyselinck, N. B. (2003). A directional strategy for monitoring Cre-mediated recombination at the cellular level in the mouse. Nat. Biotechnol. 21, 562-565. doi: $10.1038 /$ nbt 811

Schurmans, S., Schiffmann, S. N., Gurden, H., Lemaire, M., Lipp, H. P., Schwam, V., et al. (1997). Impaired long-term potentiation induction in dentate gyrus of calretinin-deficient mice. Proc. Natl. Acad. Sci. U.S.A. 94, 10415-10420. doi: 10.1073/pnas.94.19.10415

Schwaller, B., Dick, J., Dhoot, G., Carroll, S., Vrbova, G., Nicotera, P., et al. (1999). Prolonged contraction-relaxation cycle of fast-twitch muscles in parvalbumin knockout mice. Am. J. Physiol. 276(2 Pt 1), C395-C403.

Siegle, J. H., and Wilson, M. A. (2014). Enhancement of encoding and retrieval functions through theta phase-specific manipulation of hippocampus. eLife 3:e03061. doi: 10.7554/eLife.03061

Slimko, E. M., McKinney, S., Anderson, D. J., Davidson, N., and Lester, H. A. (2002). Selective electrical silencing of mammalian neurons in vitro by the use of invertebrate ligand-gated chloride channels. J. Neurosci. 22, 7373-7379.

Sohn, J., Hioki, H., Okamoto, S., and Kaneko, T. (2014). Preprodynorphinexpressing neurons constitute a large subgroup of somatostatin-expressing GABAergic interneurons in the mouse neocortex. J. Comp. Neurol. 522, 1506-1526. doi: 10.1002/cne.23477

Sparta, D. R., Hovelso, N., Mason, A. O., Kantak, P. A., Ung, R. L., Decot, H. K., et al. (2014). Activation of prefrontal cortical parvalbumin interneurons facilitates extinction of reward-seeking behavior. J. Neurosci. 34, 3699-3705. doi: 10.1523/JNEUROSCI.0235-13.2014

Stamatakis, A. M., Jennings, J. H., Ung, R. L., Blair, G. A., Weinberg, R. J., Neve, R. L., et al. (2013). A unique population of ventral tegmental area neurons inhibits the lateral habenula to promote reward. Neuron 80, 1039-1053. doi: 10.1016/j.neuron.2013.08.023

Sternson, S. M., and Roth, B. L. (2014). Chemogenetic tools to interrogate brain functions. Annu. Rev. Neurosci. 37, 387-407. doi: 10.1146/annurev-neuro071013-014048

Tamas, G., Buhl, E. H., Lörincz, A., and Somogyi, P. (2000). Proximally targeted GABAergic synapses and gap junctions synchronize cortical interneurons. Nat. Neurosci. 3, 366-371. doi: 10.1038/73936

Tamas, G., Somogyi, P., and Buhl, E. H. (1998). Differentially interconnected networks of GABAergic interneurons in the visual cortex of the cat. J. Neurosci. 18, 4255-4270.

Taniguchi, H. (2014). Genetic dissection of GABAergic neural circuits in mouse neocortex. Front. Cell. Neurosci. 8:8. doi: 10.3389/fncel.2014.00008

Taniguchi, H., He, M., Wu, P., Kim, S., Paik, R., Sugino, K., et al. (2011). A resource of Cre driver lines for genetic targeting of GABAergic neurons in cerebral cortex. Neuron 71, 995-1013. doi: 10.1016/j.neuron.2011.07.026

Taniguchi, H., Lu, J., and Huang, Z. J. (2013). The spatial and temporal origin of chandelier cells in mouse neocortex. Science 339, 70-74. doi: 10.1126/science. 1227622

Tantama, M., Hung, Y. P., and Yellen, G. (2012). Optogenetic reporters: fluorescent protein-based genetically encoded indicators of signaling and metabolism in the brain. Prog. Brain Res. 196, 235-263. doi: 10.1016/B978-0-444-59426-6.00012-4

Taymans, J. M., Vandenberghe, L. H., Haute, C. V., Thiry, I., Deroose, C. M., Mortelmans, L., et al. (2007). Comparative analysis of adeno-associated viral vector serotypes 1, 2, 5, 7, and 8 in mouse brain. Hum. Gene Ther. 18, 195-206. doi: 10.1089/hum.2006.178

Thestrup, T., Litzlbauer, J., Bartholomäus, I., Mues, M., Russo, L., Dana, H., et al. (2014). Optimized ratiometric calcium sensors for functional in vivo imaging of neurons and T lymphocytes. Nat. Methods 11, 175-182. doi: 10.1038/nmeth. 2773

Tian, L., Hires, S. A., Mao, T., Huber, D., Chiappe, M. E., Chalasani, S. H., et al. (2009). Imaging neural activity in worms, flies and mice with improved GCaMP calcium indicators. Nat. Methods 6, 875-881. doi: 10.1038/nmeth. 1398

Ting, J. T., and Feng, G. (2014). Recombineering strategies for developing next generation BAC transgenic tools for optogenetics and beyond. Front. Behav. Neurosci. 8:111. doi: 10.3389/fnbeh.2014.00111

Tukker, J. J., Fuentealba, P., Hartwich, K., Somogyi, P., and Klausberger, T. (2007). Cell type-specific tuning of hippocampal interneuron firing during gamma oscillations in vivo. J. Neurosci. 27, 8184-8189. doi: 10.1523/JNEUROSCI.168507.2007
Tye, K. M., Prakash, R., Kim, S.-Y., Fenno, L. E., Grosenick, L., Zarabi, H., et al. (2011). Amygdala circuitry mediating reversible and bidirectional control of anxiety. Nature 471, 358-362. doi: 10.1038/nature09820

van Zessen, R., Phillips, J. L., Budygin, E. A., and Stuber, G. D. (2012). Activation of VTA GABA neurons disrupts reward consumption. Neuron 73, 1184-1194. doi: 10.1016/j.neuron.2012.02.016

Verret, L., Mann, E. O., Hang, G. B., Barth, A. M., Cobos, I., Ho, K., et al. (2012). Inhibitory interneuron deficit links altered network activity and cognitive dysfunction in Alzheimer model. Cell 149, 708-721. doi: 10.1016/j.cell.2012.02.046

Wall, N. R., Wickersham, I. R., Cetin, A., De La Parra, M., and Callaway, E. M. (2010). Monosynaptic circuit tracing in vivo through Cre-dependent targeting and complementation of modified rabies virus. Proc. Natl. Acad. Sci. U.S.A. 107, 21848-21853. doi: 10.1073/pnas.1011756107

Wang, H. X., Waterhouse, B. D., and Gao, W. J. (2013). Selective suppression of excitatory synapses on GABAergic interneurons by norepinephrine in juvenile rat prefrontal cortical microcircuitry. Neuroscience 246, 312-328. doi: 10.1016/ j.neuroscience.2013.05.009

Wang, Q., Liu, C., Uchida, A., Chuang, J. C., Walker, A., Liu, T., et al. (2014). Arcuate AgRP neurons mediate orexigenic and glucoregulatory actions of ghrelin. Mol. Metab. 3, 64-72. doi: 10.1016/j.molmet.2013.10.001

Weible, A. P., Schwarcz, L., Wickersham, I. R., DeBlander, L., Wu, H., Callaway, E. M., et al. (2010). Transgenic targeting of recombinant rabies virus reveals monosynaptic connectivity of specific neurons. J. Neurosci. 30, 16509-16513. doi: 10.1523/JNEUROSCI.2442-10.2010

Wess, J., Nakajima, K., and Jain, S. (2013). Novel designer receptors to probe GPCR signaling and physiology. Trends Pharmacol. Sci. 34, 385-392. doi: 10.1016/j.tips.2013.04.006

Wickersham, I. R., Lyon, D. C., Barnard, R. J., Mori, T., Finke, S., Conzelmann, K. K., et al. (2007). Monosynaptic restriction of transsynaptic tracing from single, genetically targeted neurons. Neuron 53, 639-647. doi: 10.1016/j.neuron.2007.01.033

Wietek, J., Wiegert, J. S., Adeishvili, N., Schneider, F., Watanabe, H., Tsunoda, S. P., et al. (2014). Conversion of channelrhodopsin into a light-gated chloride channel. Science 344, 409-412. doi: 10.1126/science.1249375

Witten, I. B., Lin, S. C., Brodsky, M., Prakash, R., Diester, I., Anikeeva, P., et al. (2010). Cholinergic interneurons control local circuit activity and cocaine conditioning. Science 330, 1677-1681. doi: 10.1126/science.1193771

Wulff, P., and Arenkiel, B. R. (2012). Chemical genetics: receptor-ligand pairs for rapid manipulation of neuronal activity. Curr. Opin. Neurobiol. 22, 54-60. doi: 10.1016/j.conb.2011.10.008

Wulff, P., Goetz, T., Leppä E., Linden, A. M., Renzi, M., Swinny, J. D., et al. (2007). From synapse to behavior: rapid modulation of defined neuronal types with engineered GABAA receptors. Nat. Neurosci. 10, 923-929. doi: 10.1038/nn1927

Xu, H., Jeong, H. Y., Tremblay, R., and Rudy, B. (2013). Neocortical somatostatinexpressing GABAergic interneurons disinhibit the thalamorecipient layer 4 . Neuron 77, 155-167. doi: 10.1016/j.neuron.2012.11.004

Zemanick, M. C., Strick, P. L., and Dix, R. D. (1991). Direction of transneuronal transport of herpes simplex virus 1 in the primate motor system is strain-dependent. Proc. Natl. Acad. Sci. U.S.A. 88, 8048-8051. doi: $10.1073 /$ pnas.88.18.8048

Zhang, F., Wang, L. P., Boyden, E. S., and Deisseroth, K. (2006). Channelrhodopsin2 and optical control of excitable cells. Nat. Methods 3, 785-792. doi: $10.1038 /$ nmeth936

Conflict of Interest Statement: The authors declare that the research was conducted in the absence of any commercial or financial relationships that could be construed as a potential conflict of interest.

Received: 15 August 2014; accepted: 22 September 2014; published online: 17 October 2014.

Citation: Murphey DK, Herman AM and Arenkiel BR (2014) Dissecting inhibitory brain circuits with genetically-targeted technologies. Front. Neural Circuits 8:124. doi: $10.3389 /$ fncir.2014.00124

This article was submitted to the journal Frontiers in Neural Circuits.

Copyright (c) 2014 Murphey, Herman and Arenkiel. This is an open-access article distributed under the terms of the Creative Commons Attribution License (CC BY). The use, distribution or reproduction in other forums is permitted, provided the original author(s) or licensor are credited and that the original publication in this journal is cited, in accordance with accepted academic practice. No use, distribution or reproduction is permitted which does not comply with these terms. 